\title{
Journal Price Escalation and the Market for Information: The Librarians' Solution
}

\section{Bruce R. Kingma and Philip B. Eppard}

This article analyzes the problem of journal price escalation as one of equilibrium between two connected segments of the market for information: the library market and the market for individual subscriptions. The relationship between these two segments has been critically affected by the ready availability of cheap, high-quality photocopying, which has encouraged individuals to rely more on libraries' subscriptions to meet their information needs. The economic theories of F. P. Ramsey show that society is better-off if the costs of journals are shared by both market segments. The proposed solution is for libraries to restrict journal use to within the library and to price photocopies optimally in order to encourage an increase in private subscriptions.

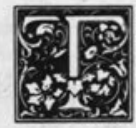

he rising prices of journal subscriptions have been a continuing topic of interest and lament for librarians and others for well over a decade. In stringent fiscal times the problem seems more pressing than ever, and yet no effective solution has emerged from the numerous attempts to analyze the problem. Several authors in information science and economics have evaluated the problem of journal price escalation. Richard M. Dougherty and Brenda L. Johnson, among others, have attributed journal price escalation simply to overly greedy publishers seeking to extract ever greater profit from libraries.' Malcolm Getz and David W. Lewis, among others, have suggested that high subscription prices are necessary in order for publishers to survive, given the unique downward-sloping average cost curves that publishers face. ${ }^{2}$
Yoram Barzel and Janusz Ordover and Robert D. Willig have accurately described the market for journals as an equilibrium between the two connected segments of the market for information, namely, the library market and the market for personal subscriptions. ${ }^{3}$ James Talaga and Jean Walstrom Haley have outlined the various reasons why publishers charge higher subscription rates to libraries than they do to individuals. ${ }^{4}$

While these explanations have a place in describing the price that libraries are charged for journal subscriptions, they do not fully explain what has changed in the market to cause the dramatic price escalation of the past thirty years. Only S. J. Liebowitz has identified the increase in library subscription rates as the result of the increasing quality and decreasing real price of photocopying. ${ }^{5}$ However, he failed to examine the economic welfare

Bruce R. Kingma is a professor at the School of Information Science and Policy, Rockefeller College of Public Affairs and Policy, and the Department of Economics, and Philip B. Eppard is a professor at the School of Information Science and Policy, Rockefeller College of Public Affairs and Policy, University at Albany, State University of New York, Albany, New York 12222. The authors would like to thank Thomas Galvin and Ben-Ami Lipetz for their helpful comments. 
implications of the two market segments, to explain the cost structure of the industry, or to offer any solutions to librarians. In addition, Liebowitz, Barzel, and Ordover and Willig are largely theoretical in their analyses and fail to offer any practical solutions useful to librarians.

Articles in library and information science journals have focused on the decreasing average cost curves-or high first-copy costs-of journal publishers and the segmentation of the market for journals into private and institutional subscriptions. The high cost of setting up the first copy of a journal implies that publishers must charge a price above the cost of subsequent copies in order to recoup their initial expense. The segmentation of the market into institutional and private subscriptions allows publishers to charge separate prices to each part of the market. Libraries, which will normally pay more than individuals for a journal before canceling their subscriptions, are charged a higher price.

However, while these authors may be correct in assuming that journal publishers face downward sloping average cost curves, these economic facts of life for publishers need not necessarily imply higher journal prices for libraries. In particular, their hypothesis fails to explain why publishers could survive thirty years ago but now must charge prices significantly higher in real terms.

The unwillingness of libraries to cancel journal subscriptions when prices increase (what is termed in economics the inelastic demand of the library market) and the fact that the market for library subscriptions can be segmented from that for personal subscriptions enable journal publishers to charge a price for libraries that is above their marginal cost. However, this explanation ignores the causes of inelastic library demand, the nature of publishers' costs, and, more importantly, the connection between the library demand for journals and the demand for personal subscriptions. ${ }^{6}$

Understanding the economics of information markets is critical to understanding the problem of journal price escalation. The problem cannot be an- swered by solely looking at the demand and supply of journals to libraries. The problem is one of market equilibriums not only in the library market but also in the market for private subscriptions and in the important relationship between these markets. Academic library demand for journal subscriptions is (or should be) directly related to the desires of the faculty and students that the library serves. Individual demand for journals is related to the benefit and cost of a journal subscription and the benefit and cost of the next best alternative, i.e., using the library's subscription. It is the relationship between these two parts of the market for journals that is critical to understanding the price of journals and the solution to the problem.

\section{COMMON MISUNDERSTANDINGS AND FALSE SOLUTIONS}

Several common misunderstandings exist in the debate over journal pricing. The first misunderstanding is that the sole reason that publishers charge higher prices to libraries is because librarians are unwilling to cancel subscriptions when prices increase. Michael E. D. Koenig (1984), ${ }^{7}$ Lewis, and Getz, among others, have corrected this fallacy. The publisher's profit-maximizing price is determined by the combination of the library's inelastic demand and the publisher's marginal cost for journals. When contemplating a price increase for a journal, publishers compare the estimated percentage decrease in the number of subscriptions resulting from the price increase and the resulting change in revenue, with the decrease in costs from the decreased number of subscriptions. There will be no incentive to increase subscription prices if the price increase is so high that too many subscriptions are canceled. The publisher will increase price only if it promises an increase in profits, or a net gain in revenues.

All producers or firms set prices in order to maximize profits. Even nonprofit publishers, faced with competition from for-profit publishers, may find it necessary for survival to charge a price 
that maximizes profit. In a competitive market, the market price adjusts in such a way that the price charged and the level of output sold allow for only costefficient publishers to survive.

For this same reason, it is unlikely that switching to an electronic information network will significantly reduce the library's price of acquiring information. Reviewers, referees, and other agents who control the process of evaluating and disseminating the information may still find it impossible to resist the profit motive. Individual and institutional demand for the information would not change, while the cost of providing the information in electronic format rather than in print would decrease only slightly. The resulting market price for library access to scholarly information in electronic media would be reduced only by a fraction of the decrease in cost from the traditional method of journal publication. Only a complete usurpation of the electronic journal by academic institutions, as suggested by Paul Metz and Paul M. Gherman, would dramatically alter this situation. ${ }^{8}$

A second, more recent misconception in the literature on escalating journal prices is that the inelastic library demand and publishers' costs are the principal cause of price escalation over the past three decades. While this argument explains why subscription prices are higher for libraries than for individual subscribers, it does not explain the disproportionate increase in library subscription prices over the past thirty years.

What has changed is the way in which individual subscribers acquire information. As noted by Liebowitz, since the introduction of the Xerox 914 copier in 1959 , the quality of photocopies has increased. Over this same period, little real increase has occurred in the price which libraries charge for photocopying. Most libraries have increased the price of a photocopy from five to ten cents at some point in the past ten years. However, the consumer price index rose 300 percent from 1960 to 1988 , implying that the real price of a photocopy has decreased. This has resulted in an increased demand for photocopies of journal articles, a more elastic demand for private journal subscriptions, a more inelastic demand for library journal subscriptions, and, ultimately, a dramatic increase in the library's price of journals. Understanding the segmented market for journal demand and supply and the connection between the two market segments is important to understanding fully how photocopying prices have influenced the price of journal subscription.

\section{SEGMENTED MARKETS: JOURNAL DEMAND AND SUPPLY}

Publishers face a market for journal subscriptions that is segmented into two parts: library subscriptions and individual subscriptions. The advantage of having a segmented market is that a producer can choose his price and level of output in each market segment to maximize profit. The sum of the profit from each market segment will exceed the maximum profit available from the market if it cannot be segmented. Typically, a producer may be able to segment markets by geographic location (different countries), consumer tastes, or gender. If possible, the producer will charge a different price in France versus the United States, in the city versus the country, to men versus women, or to single adults versus families or children.

In many industries with segmented markets, the segments are independent of one another, meaning that the price charged in one market segment has little influence over the profitability of the other segment. In the journal subscriptions market, the two market segments are not independent. The availability and accessibility of a journal in a library directly affect the demand for private subscriptions. The price that libraries are charged influences the demand for library subscriptions, and the number of library subscriptions sold influences the demand for private subscriptions. Likewise the expense of a private subscription to a journal influences the number of academic subscribers. This, in turn, influences the demands placed on librarians 
by faculty members and students for the library to subscribe to the journal. Therefore, the price charged for private subscriptions ultimately influences library demand.

The connection between these two market segments implies that the price a publisher charges in one segment influences the profitability of the sales in the other market segment and vice versa. Therefore, in order to understand the market for journal publications, it is critical to understand the link between the two market segments.

\section{THE MARKET FOR INFORMATION}

The missing key to the evaluation of journal prices is a complete understanding of the market for information. The market for information connects the two segments of the market for journals. In the two market segments, neither publishers' motivations-level of greednor publishers' real costs have changed significantly over the past three decades. The changes that have occurred have been in the market for information.

Information is the key to any journal subscription. Although academic scholars may trade information informally, publication in a refereed journal lends credibility to the research of a particular author. This credibility comes from the author's articles having passed the scrutiny of one or more peer reviewers and an editor or editorial committee. The peer review system is imperfect, but even critics of it such as James M. Banner, Jr., and Michael McGiffert recognize it as an essential element in scholarly communication. ${ }^{9}$ The credibility of a journal publication is significant enough that scholars use it as a measure of the quality of the article and as one of the standards for making decisions on tenure and promotion. Problems have arisen because of the increase in the number of scholarly journals that publish many articles never cited in later research. These articles seem to some people to exist solely for the purpose of padding their authors' bibliographies in order to secure promotion, tenure, or research grants. ${ }^{10}$ It has been suggested that academics find an alternative method for tenure evaluation in order to reduce library demand for journals. If academics were to decrease their reliance on publications for tenure, these lesser quality journals would no longer be necessary. Talaga and Haley suggest that the best solution to the journal price problem may lie in reevaluating traditional methods of scholarly communication. However, it is unlikely that the familiar and relatively efficient system of using journal publications for evaluating scholarly accomplishments and for making decisions on tenure will be replaced by a more efficient alternative. As Charles B. Osburn noted in an article reviewing the history of journal publication, "Review of the manuscript by peers in the field who are qualified to judge the significance of the contribution has been the basis of the substantive role of the journal since its beginnings in the seventeenth century."11

Scholars have two ways of acquiring information from journals: through personal subscriptions and through library subscriptions. The demand for personal subscriptions to a journal is a reflection of the benefit that individuals receive from owning copies of the journal. The inelastic library demand for journals is (or should be) a reflection in part of the demand for information by faculty and students who do not have personal subscriptions.

While scholars demand information, they also seek to maximize their net personal benefit from the information. Their maximum net personal benefit comes from maximizing the difference between the benefit of the information and the cost of acquiring it. If the benefit of the information is the same, regardless of the form in which it is received, then maximizing net personal benefit is the same as minimizing the cost of acquiring the information. This process suggests that we compare the price of a personal subscription to the journal to the cost of using the library's subscription.

Acquiring the information from the library's journal subscription only costs the time spent in the library. A scholar must spend time walking to and from 
the library, but once copied, the article can be conveniently read at home or in the office. Nearly all faculty members have filing cabinets filled with copies of journal articles, labeled and alphabetized. Given that the cost of copying a few articles from the library's copy of the journal is lower than the cost of a personal subscription, a faculty member minimizes the cost of acquiring the information by using the library's subscription.

Of course, some academics may receive more net benefit from a personal subscription to the journal. A bound copy is more durable. However, most find it more cost effective to use the library's subscription for all but one or two of the most important journals in their field. Long runs of journals may create an aura of authority in the faculty member's office, but shelf space is as finite in the office as it is in the library.

For research purposes, however, a personal library of copies of journal articles may provide more net benefit and be more cost effective than a journal subscription. Copies of articles can be sorted and cataloged by specialization, author, topic, or other method while full issues of journals cannot. If extra copies must be made for students or others, a photocopy of a journal article is easier to duplicate than the original journal article. In addition, copies of journal articles can often be made by graduate students at the expense of the department. In this way the information can be obtained with the minimum possible expenditure of time and money.

Since the introduction of high quality photocopiers in 1959, the nominal price of a photocopy in most libraries has increased very little. As the quality of copies has increased, the real cost to users has decreased, and scholars have become more reliant on their private libraries of photocopied articles rather than on personal journal subscriptions. Increased reliance on photocopies of journal articles has resulted in a more inelastic demand by libraries for journal subscriptions. At the same time, the elasticity of demand for private subscriptions has increased, preventing publishers from charging private subscribers prices above the cost of obtaining a copy from the library. The availability and quality of photocopying within the library have given scholars a lower cost alternative to acquiring information, requiring the real cost of private journal subscriptions to decrease and the library demand to become more inelastic.

Is this the socially optimal way of providing information to society? Should libraries be charged a premium by publishers to pay for the high fixed costs of journal publication while private subscribers are charged the marginal cost of printing? According to economic theory the answer is no.

\section{THE ECONOMICS OF JOURNAL SUBSCRIPTIONS AND SOCIAL WELFARE}

Given the assumption that the high fixed or first copy cost of a journal results in a downward sloping average cost curve, a publisher must charge prices above marginal cost in order to avoid incurring a financial loss. ${ }^{12}$ The only question that remains relates to the price that should be charged in order to maximize what economists define as social benefit or the net benefit to libraries, scholars, and publishers.

In 1927, the economist F. P. Ramsey proved that when prices above marginal cost must be charged to cover costs, then it is in society's best interests to charge above marginal cost prices in all markets. In other words, the best interests of society are served by the producer recovering the high fixed costs of production from all markets rather than from only one. ${ }^{13}$ The degree of price difference between the socially efficient price and the marginal cost depends on the elasticity of demand in each market.

Economists can analyze the benefit in dollar terms by comparing the price a consumer is willing to pay for a journal subscription with the marginal cost of producing it. If someone is willing to pay $\$ 30$ for a subscription which costs $\$ 10$ to produce, the net social benefit is $\$ 20$. This $\$ 20$ of social benefit will be divided 
between the consumer and the producer, depending on the price charged for the subscription.

Using this definition of social benefit, Ramsey's result for optimal journal prices is illustrated in figures $\mathrm{A}-1, \mathrm{~A}-2$, B-1, and B-2 and tables 1, 2, and 3 on the following pages. Figure A-1 represents the market for journal subscriptions by libraries. Figure B-1 represents the market for journal subscriptions by academics. The demand in markets $A$ and $B$ is represented by $\mathrm{Da}$ and $\mathrm{Db}$ respectively. Points on Da are shown in table 1, columns 1 and 2. Points on $\mathrm{Db}$ are shown in table 1, columns 3 and 4 . Assume that the marginal cost (MC in the figures) of a journal subscription is $\$ 10$. Table 1 , case 1 is illustrated in figures A-1 and B-1. In figure A-1, libraries are charged $\$ 30$ per subscription and purchase 350 subscriptions. In figure B-1, individuals are charged $\$ 10$ per subscription and purchase 1,300 subscriptions.

The shaded area in figure A-1 represents the benefit lost when people acquire information from the library. This loss results from publishers charging prices above marginal cost. All subscriptions between $Q_{a}=350$ and $Q_{e}=475$ give libraries a greater benefit (defined by $\mathrm{D}_{\mathrm{a}}$ ) than the cost of producing these additional subscriptions (defined by $\mathrm{MC}$ ).

This result is a straightforward application of standard microeconomic theory. The marginal benefit of a given subscription is the price a consumer (library or individual) is willing to pay for it. In each market the price a consumer is willing to pay for a given subscription is represented by the demand curve. The net benefit to a consumer of a given subscription is the amount he is willing to pay for it minus the price he pays. This defines the consumer surplus. In figure A-1, a library is willing to pay approximately $\$ 31$ for the 349 th subscription. If the library purchases the 349 th subscription for $\$ 30$, its consumer surplus is $\$ 1$. Society (producers plus consumers) fails to receive the maximum net social benefit possible when subscriptions valued above their marginal cost are not produced and sold. A social loss, or loss of library consumer surplus, exists in market $\mathrm{A}$ because the amount libraries benefit from subscriptions between $\mathrm{Q}_{\mathrm{a}}$ and $Q_{e}$ is greater than the marginal cost of producing these subscriptions. For the 400th subscription, a library is willing to pay approximately $\$ 19$, a price greater than the $\$ 10$ it costs to print it. However, at a price of $\$ 30$ libraries are prevented from purchasing more than 350 subscriptions.

In case 1 , the social loss in the library market is the dark shaded area in figure A-1. The value of this area is the average value of a subscription to libraries that cannot afford it times the number of libraries that cannot afford to subscribe minus the cost of producing these extra subscriptions. This equals:
$0.5 \times(\$ 30+\$ 10)$
-the average value of a subscription to libraries without one
$x(475-350)$
-the number of libraries which cannot afford a subscription
$-\$ 10 \times(475-350)-$ the cost of these extra subscriptions
$=\$ 1,250$ -social loss in the library
market.

The value of a subscription to the libraries that can afford to subscribe can be calculated in a similar way. The value to these libraries equals the average price they were willing to pay for a subscription times the number of libraries, minus the amount they actually paid. In case 1 , this equals:

$\begin{array}{ll}0.5 \times(\$ 86+\$ 30) & \begin{array}{l}\text {-the average value of } \\ \text { a subscription to librar- } \\ \text { ies with one } \\ \text {-the number of li- } \\ \text { braries with a subscrip- } \\ \text { tion }\end{array} \\ =\$ 350 & \begin{array}{l}\text { the amount they } \\ \text { paid for their subscrip- } \\ \text { tions } \\ \text { total benefit to } \\ \text { libraries with } \\ \text { subscriptions (table 2, } \\ \text { case 1, column 10). }\end{array}\end{array}$

In market $\mathrm{B}$, the market for individual subscriptions, publishers charge $\$ 10$, which is equal to the marginal cost of a subscription. In market B, all consumers 
TABLE 1

\begin{tabular}{lcccccc}
\hline \hline & $\begin{array}{c}\text { Library } \\
\text { Journal Price } \\
(1)\end{array}$ & $\begin{array}{c}\text { Quantity of } \\
\text { Library } \\
\text { Subscriptions } \\
(2)^{*}\end{array}$ & $\begin{array}{c}\text { Individual } \\
\text { Journal Price } \\
(3)\end{array}$ & $\begin{array}{c}\text { Quantity of } \\
\text { Individual } \\
\text { Subscriptions } \\
(4)^{+}\end{array}$ & $\begin{array}{c}\text { No. of Library } \\
\text { Subscriptions } \\
\text { Gained Rel. to } \\
\text { Case 1 } \\
(5)\end{array}$ & $\begin{array}{c}\text { Individual } \\
\text { Subscriptions } \\
\text { Lost Rel. to } \\
\text { Case 1 } \\
(6)\end{array}$ \\
\hline Case 1 & $\$ 30$ & 350 & $\$ 10.00$ & 1,300 & - & - \\
Case 2 & 25 & 381 & 11.10 & 1,245 & 31 & $(55)$ \\
Case 3 & 20 & 413 & 12.50 & 1,175 & 63 & $(125)$ \\
Case 4 & 15 & 444 & 14.50 & 1,075 & 94 & $(225)$ \\
\hline
\end{tabular}

* Quantity of library subscriptions sold assumes demand for library subscriptions is $P=86-0.16 Q$

+ Quantity of individual subscriptions sold assumes demand for individual subscriptions is $\mathrm{P}=36-0.02 \mathrm{Q}$.

\section{TABLE 2}

\begin{tabular}{cccccc}
\hline & $\begin{array}{c}\text { Average Value of } \\
\text { a Library } \\
\text { Subscription } \\
(7)^{p}\end{array}$ & $\begin{array}{c}\text { Average Value of } \\
\text { an Individual } \\
\text { Subscription } \\
(8)^{t}\end{array}$ & $\begin{array}{c}\text { Publisher Profit } \\
(9)^{ \pm}\end{array}$ & $\begin{array}{c}\text { Total Benefit to } \\
\text { Libraries of } \\
\text { Subscriptions } \\
(7) \times(2) \\
(10)\end{array}$ & $\begin{array}{c}\text { Total Benefit to } \\
\text { Individual of } \\
\text { Subscriptions } \\
(8) \times(4) \\
(11)\end{array}$ \\
\hline Case 1 & $\$ 28.00$ & $\$ 13.00$ & $\$ 7,000$ & $\$ 9,800$ & $\$ 16,900$ \\
Case 2 & 30.50 & 12.45 & 7,085 & 11,621 & 15,500 \\
Case 3 & 33.00 & 11.75 & 7,063 & 13,629 & 13,806 \\
Case 4 & 35.50 & 10.75 & 7,058 & 15,762 & 11,556 \\
\hline
\end{tabular}

* The average value of a library subscription is $0.5(P+\$ 86)-P$, where $\$ 86$ is the highest price a library would pay for the subscription and $P$ is the actual price paid.

+ The average value of an individual subscription is $0.5(P+\$ 36)-P$.

$\ddagger$ Publisher profit is QIND. (PIND. - \$10) + QUIB. $\left(P_{\text {LIB }}-\$ 10\right)$, where $\$ 10$ is the cost of a single subscription.

\section{TABLE 3}

Total Benefit to Libraries Plus Individuals (10) + (11)

Case 1

$\$ 26,700$

Case 2

27,121

27,435 27,318

Case 3
Total Benefit to Society

$(9)+(10)+(11)$
$\$ 33,700$

34,206

34,498

34,376 


\section{Price}

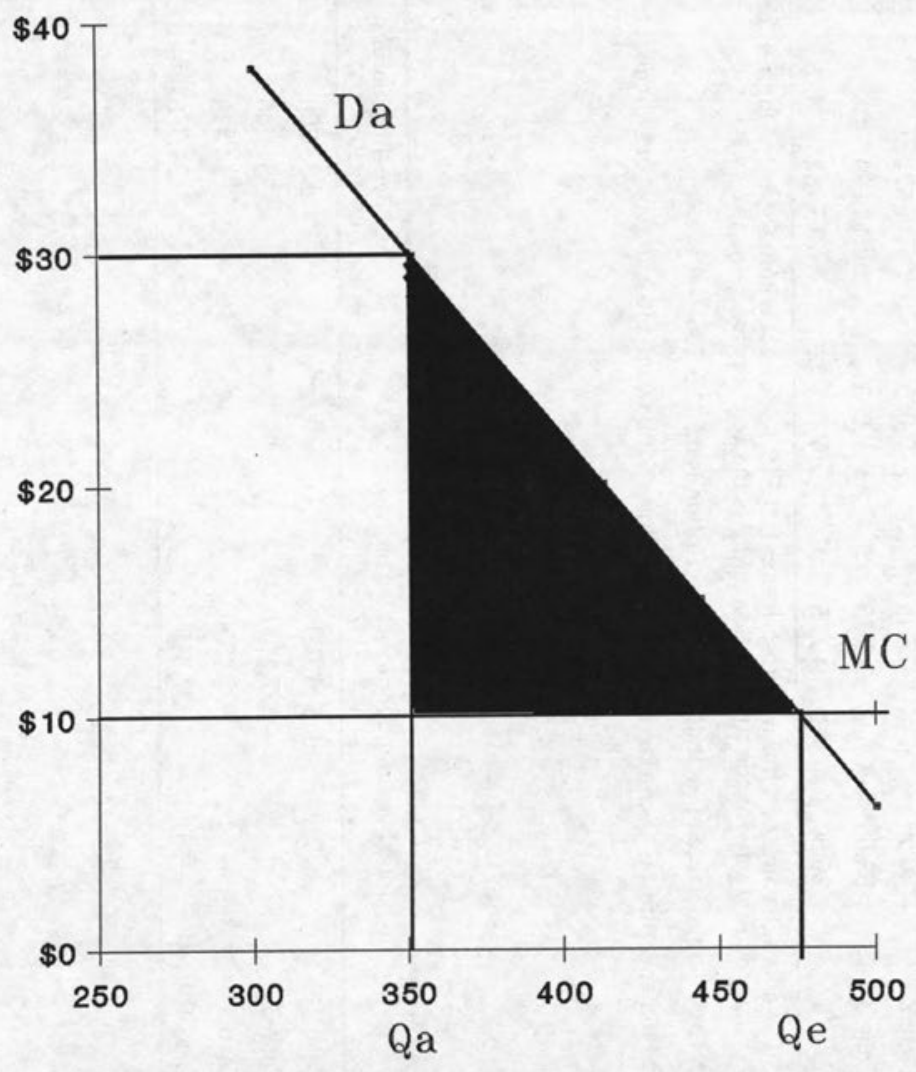

FIGURE A-1

Library Market

\section{Price}

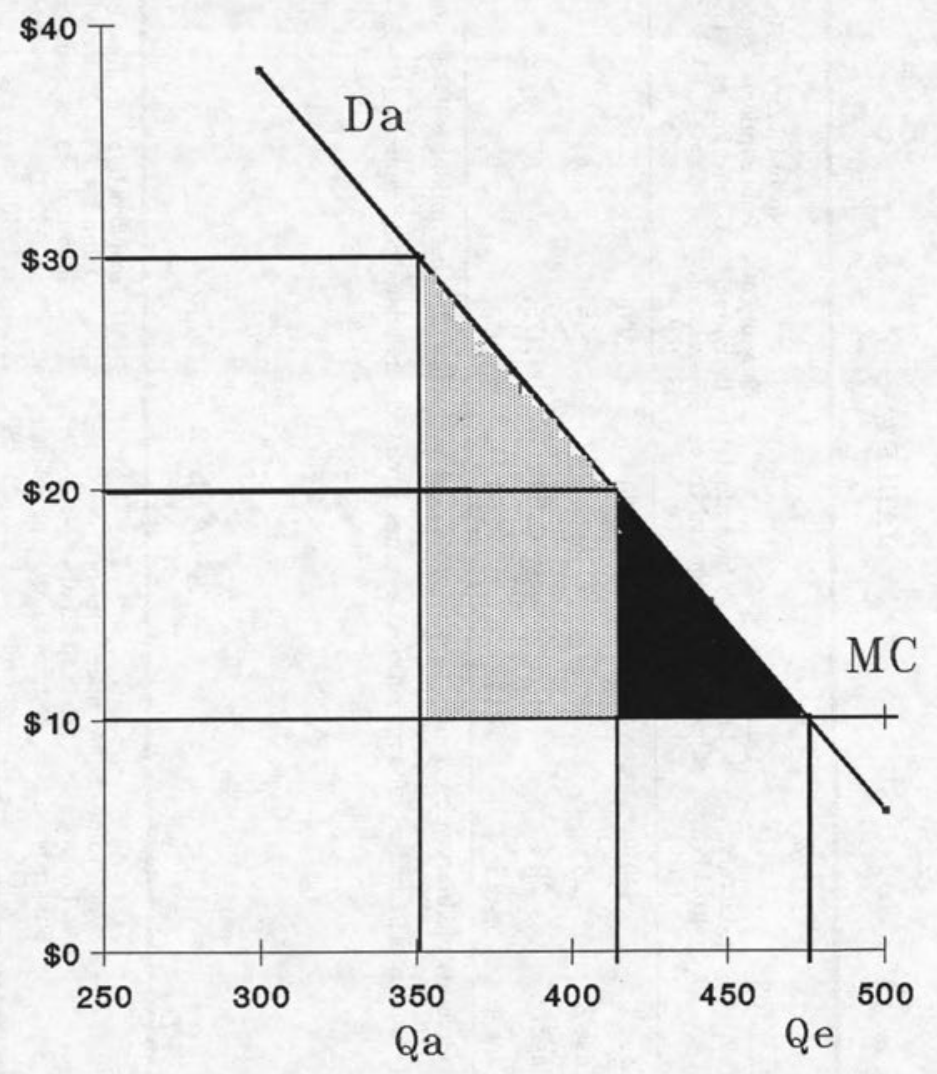

FIGURE A-2

Library Market 


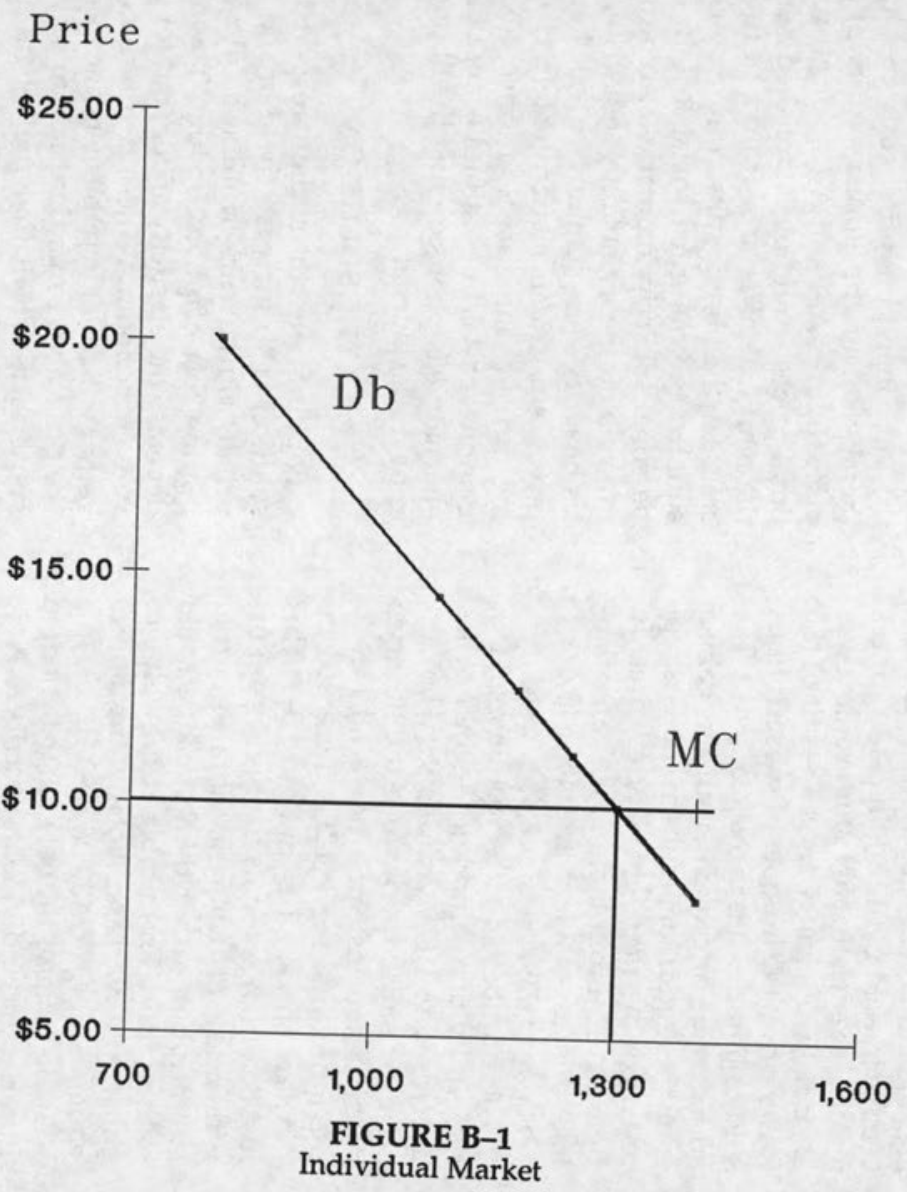

\section{Price}

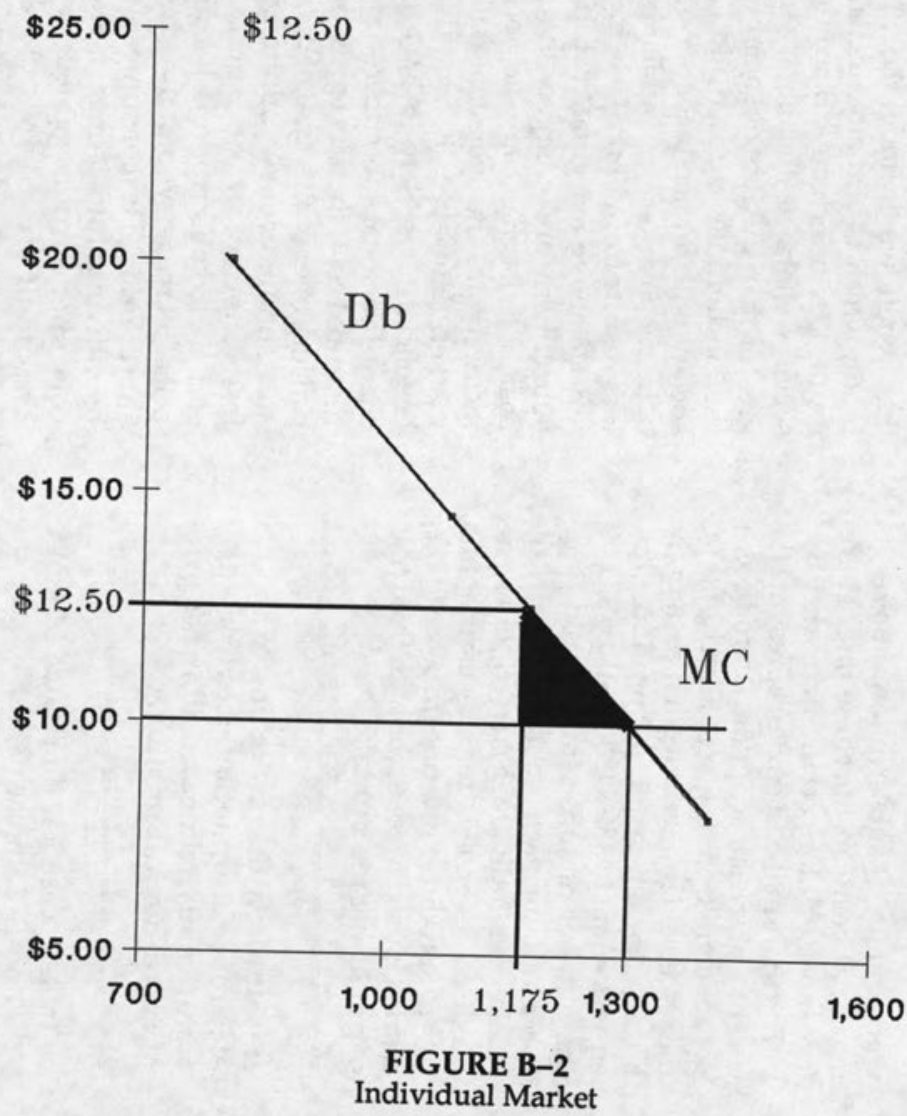


who value a subscription above its marginal cost can purchase one. Therefore, no social loss occurs in market B.

The marginal cost curve represents the cost of a given subscription. A producer's net revenue from a given subscription is the price paid minus marginal cost. In the library market, case 1 , net producer revenue is equal to $350 \times(\$ 30-\$ 10)=\$ 7,000$, the number of subscriptions sold times the profit on each subscription. In the market for individual subscriptions, net producer revenue is zero. By assumption, this net producer revenue from the library market is used to cover the high fixed costs of producing the journal.

It is unlikely that switching to an electronic information network will significantly reduce the library's price of acquiring information.

Table 1, case 3 is illustrated in figures A-2 and B-2. In case 3, the library subscription price has been lowered to $\$ 20$, and the individual subscription price has been increased to $\$ 12.50$. In case 3 , prices are chosen such that net producer revenue is virtually unchanged. As a result of the lower price, the number of subscriptions sold to libraries has increased to 413 . The added value or consumer surplus gained from these additional subscriptions is represented by the light shaded area in figure A-2. From table 2, we can calculate this area which equals $\$ 13,629$ $\$ 9800=\$ 3,829$.

The number of subscriptions sold in the individual market segment has decreased to 1,175. Academics who cancel their subscriptions use the library's subscription instead. The social loss in the individual market has increased by the dark shaded area in figure B-2. This lost benefit represents the higher opportunity cost of using the library journal subscription rather than one's personal subscription. From table 2, the value of subscriptions canceled by academics equals $\$ 16,900-\$ 13,806=\$ 3,106$.

Table 3 shows the net gain in benefit to libraries and individual subscribers. Note that when we include the publisher's profit, which is virtually unchanged, the result does not change. Since the gain in social welfare in the library market is greater than the loss of social welfare in the individual subscription market, society will, on net, be better off.

In the market for publishing, social loss results from libraries being charged a price above marginal cost. If personal subscribers are charged the marginal cost of a journal copy, no social loss is incurred in the personal subscription market. However, it would be more beneficial for society to have publishers charge personal subscribers a price above marginal cost, thereby spreading the social loss over each segment of the market and simultaneously minimizing social loss. The few private subscribers that end their subscriptions because of the price increase would use the library's subscription. The consumer surplus lost by individual subscribers is less than the consumer surplus gained by libraries. The profit gained by publishers from customers who do not cancel their private subscriptions could be used to cover the publishers' high first copy cost and thereby lower the library subscription price (figures A-1 and A-2). Socially optimal prices would be established when the marginal social loss from a price increase in the library subscription market equaled the marginal social loss in the personal subscription market. According to economic theory, not only should libraries be charged a premium, but so should private subscribers. Unfortunately, charging private subscribers a price above marginal cost is impossible because their alternative is photocopying the library's copy of the journal.

\section{THE SOLUTION}

For librarians, the socially responsible solution is to increase the demand for private journal subscriptions by increasing the cost of photocopying. This will decrease the elasticity of demand for private subscriptions. These two factors together will result in publishers' increasing the price above marginal cost to private subscribers. Profit that publishers gain 
from the market for private subscriptions might result in publishers' decreasing library subscription prices. The change in library subscription prices depends on, among other things, the libraries' elasticity of demand for journal subscriptions. However, even if the prices of journal subscriptions did not decrease, the net cost-the price minus the increase in photocopy revenues-to the library will decrease. ${ }^{14}$

\section{Since the introduction of high quality photocopiers the nominal price of a photocopy in most libraries has increased very little.}

The usual economic suggestion of library user fees is not a morally acceptable solution to most librarians. However, the librarians' credo of free flow of and open access to information would seem to imply that access to information be free within the confines of the library. This does not require that the library unwittingly promote a system in which academics are free to cancel their subscriptions to journals in order to produce lower cost alternatives for themselves. In fact, if higher copying costs do induce more individuals to subscribe and thereby influence publishers to reduce journal subscription prices to libraries, then the net effect will be that the library has more money to subscribe to more journals, thereby enhancing access to information.

The solution is to continue free access to information and simultaneously force individuals to pay more for their private libraries of photocopies by restricting journal use to within the library and increasing photocopying fees. Increasing the cost of obtaining a private copy of the information from a library will increase the demand for personal subscriptions, thereby making the demand in that market segment more inelastic. (Admittedly some journals are so specialized that few individuals will be inclined to subscribe to them.) These changes in the demand for private subscriptions will enable publish- ers to increase the price of a private subscription above marginal cost.

Profit obtained from the market for private subscriptions may be used to decrease the price of library subscriptions. In addition, library photocopying revenues may increase. The net revenue gained from a decrease in journal prices plus the increase in library photocopy revenues can be used to purchase additional books or journals. In the end, more libraries will be able to subscribe to more journals and the number of private subscribers should increase..$^{15}$

The socially optimal price of a photocopy is a simple calculation for any economist. However, it depends on an accurate estimate of the price elasticity in each market. Librarians would have to estimate the price elasticity of library subscriptions, private subscriptions, the supply of journals, and photocopying along with all of the relevant cross-price elasticities. To the best of our knowledge, these numbers have never been estimated. In addition, the solution for the optimal price of photocopying may not yield the socially optimal above marginal cost prices for journals. This depends on the response of publishers to an increase in the demand for private subscriptions.

There are some practical considerations for a library to take into account when setting photocopy prices. Academic libraries serve students as well as faculty, and increased photocopy prices may pose a greater burden on students than on faculty. They may in fact encourage greater mutilation of periodicals in the library. Surveys by Dana Weiss and Terri L. Pederson relating to theft and mutilation suggest that photocopy costs are not really a major factor contributing to mutilation, but higher costs may change that situation. ${ }^{16}$

Another area of concern is potential violation of the copyright law provisions that permit library photocopying. According to Section 108 of the Copyright Act of 1976, the section that elaborates the conditions under which libraries and archives may reproduce copyrighted material, such copying is to be done "without any purpose of direct or indirect commercial 
advantage." As James S. Heller has suggested, libraries may run the risk of violating this provision of the law if their photocopying services seem to be generating a profit. ${ }^{17}$ But the same section of the law relieves a library from liability for infringement "for the unsupervised use of reproducing equipment located on its premises: Provided, That such equipment displays a notice that the making of a copy may be subject to the copyright law."

Finally, the ethics of access and the goodwill and support of the faculty should be considered. Increased photocopy charges would not, strictly speaking, hinder access to materials. Patrons would still have the option of reading the journal in the library and taking notes, precisely the way research was done for generations before the proliferation of cheap photocopying. This approach would arguably instill better research habits and therefore promote better research. Access is diminished when journal subscriptions are canceled because of rising prices. Faculty no doubt would be upset at any steps that restrict easy and unlimited photocopying. But, faced with the only practical alternative, canceling subscriptions altogether, faculty members should acquiesce to the new costs. What may seem at first a restriction on access would probably, in the end, promote greater access. Not only would subscriptions not have to be canceled, but potential additional funds from copying fees and/or reduced library subscription rates could allow the library to purchase additional materials.

\section{REFERENCES AND NOTES}

1. Richard M. Dougherty and Brenda L. Johnson "Periodical Price Escalation: A Library Response," Library Journal 27-29 (May 15, 1988).

2. Malcolm Getz, "How Journals Are Priced," Bottom Line: A Financial Magazine for Librarians 2:4:37-39 (Dec. 1988); David W. Lewis, "Economics of the Scholarly Journal," College \& Research Libraries 50:674-88 (Nov. 1989).

3. Yoram Barzel, "The Market for a Semipublic Good: The Case of the American Economic Review," American Economic Review 61:665-74 (Sept. 1971); Janusz Ordover and Robert D. Willig, "On the Optimal Provision of Journals qua Sometimes Shared Public Goods," American Economic Review, 68:324-38 (June 1978).

4. James Talaga and Jean Walstrom Haley, "Marketing Theory Applied to Price Discrimination in Journals," Journal of Academic Librarianship 16:348-51 (Jan. 1991).

5. S. J. Liebowitz, "Copying and Indirect Appropriability: Photocopying of Journals," Journal of Political Economy, 93:945-57 (1985).

6. Elasticity of demand measures the responsiveness of quantity demanded to a change in price. The more elastic demand is, the less tolerant consumers are of an increase in price, and the more they will decrease their consumption. If demand is inelastic, consumers will be willing to pay higher prices.

7. Michael E. D. Koenig, "Serials Dual Pricing: The Librarians' Hobgoblin," Serials Librarian, 8:25-28 (Spring 1984).

8. Paul Metz and Paul M. Gherman, "Serials Pricing and the Role of the Electronic Journal," College \& Research Libraries, 52:315-27 (July 1991).

9. James M. Banner, Jr., "Preserving the Integrity of Peer Review," Scholarly Publishing 19:109-15 (Jan. 1988); Michael McGiffert, "Is Justice Blind? An Inquiry into Peer Review," Scholarly Publishing 20:43-48 (Oct. 1988).

10. See, for example, David P. Hamilton, "Publishing by-and for?-the Numbers," Science, 250:1331-32 (Dec. 7, 1990) and "Research Papers: Who's Uncited Now?" Science 251:25 (Jan. 4, 1991) together with the letters of rejoinder in Science 251:1408-09 (Mar. 22, 1991).

11. Charles B. Osburn, "The Place of the Journal in the Scholarly Communications System," Library Resources and Technical Services 28:315-24 (Oct./Dec. 1984).

12. For an excellent explication of downward sloping average cost curves and publisher profits see Lewis, "Economics of the Scholarly Journal," 674-88. 
13. F. P. Ramsey, "A Contribution to the Theory of Taxation," Economic Journal 37:47-61 (Mar. 1927). Ramsey's theory was originally used to calculate the optimal tax rate in each market. Here we can use it to calculate the optimal level of markup in each market to cover fixed costs.

14. Another way to increase the opportunity cost of using the library's copy of a journal would be for the library to cancel its subscription and make patrons use interlibrary loan to gain access to the journal, thus increasing the time a patron must wait in order to read the journal, and thereby increasing his cost of acquiring the information. Talaga and Haley as well as other analysts have urged this approach to increasing the elasticity of library demand. Copyright restrictions on how many requests for articles in recent journals a library may request on interlibrary loan might limit how many journals a library could cancel without seriously impairing its level of service.

15. After prices adjust, the net effect on the number of private subscribers, library subscribers, journal prices, and photocopying revenues depends on the percentage change in the number of library subscribers, private subscribers, and photocopiers relative to the change in the price in all three of these markets. For a more technical treatment of the possible effects from library user fees, see Ordover and Willig (note no. 3).

16. Dana Weiss, "Book Theft and Book Mutilation in a Large Urban University Library," College \& Research Libraries 42:341-47 (July 1981) Terri L. Pedersen, "Theft and Mutilation of Library Materials," College \& Research Libraries 51:120-28 (Mar. 1990)

17. James S. Heller, "Copyright and Fee-Based Copying Services," College \& Research Libraries 47:28-37 (Jan. 1986). 


\section{New from ALA Boo
Meeting the information demands of today's library and beyond.}

\section{FISCAL Directory of Fee-Based Research and Information Services Steve Coffman, compiler}

Approximately 550 listings of fee-based information services providers, including libraries and commercial sources, detail products, services, prices, subject strengths and resources available. Copublished by the Los Angeles Public Library.

$\$ 65.00$ pbk. 650 p. 1992

ALA Order Code 2161-2-0011

\section{Major U.S. Statistical Series:}

Definitions, Publications, Limitations

Jean Slemmons Stratford

and Juri Stratford

A specialized reference work compiled to provide the reader an understanding of a wide variety of federal statistical data and guidance in locating the published series which report them on a regular basis.

\section{$\$ 27.50$ pbk. $\quad 150$ p. 1992}

ALA Order Code 0600-1-0011

\section{The United States in the Global}

\section{Economy: Challenges and Policy}

Choices

The Last Quarter Century: A Guide to the Issues and the Literature, \#2

John J. Accordino

Accordino explores how the emerging global economy affects domestic economic health, presents policy alternatives and provides readers the means to evaluate the various approaches. Economic, industrial and trade policies are covered from conservative, liberal, and radical positions.
$\$ 38.00$ pbk. $\quad 450$ p. 1992

ALA Order Code 0591-9-0011
Available from the Association
of College and Research Libraries

New!

Women's Studies Collection

Development Policies

Collection Development and Bibliography

Committee, Women's Studies Section, ACRL

Complete policy statements from 16 university libraries illustrate the range of issues unique to women's studies and provide models of existing policies. The RLG Conspectus: Women's Studies supplemental guideline is included as an appendix.

$\$ 35.95$ pbk. $\quad 122$ p. 1992

ALA Order Code 7596-8-0011

\section{The Evolving Educational Mission} of the Library

Betsy Baker and Mary Ellen Litzinger

Strategic issues on instructional programs, librarians' roles on campus, information literacy, the information explosion, new educational constituencies, and the resultant need for changes in the information science curricula are presented.

$\$ 29.95$ pbk. 202p. 1992

ALA Order Code 7584-4-0011

American Library Association

50 East Huron Street

Chicago, IL 60611

To order call 1-800-545-2433 and press 7 . 